\title{
Hepatotoxicity of Methanol Seed Extract of Aframomum melegueta [Roscoe] K. Schum. (Grains of paradise) in Sprague-Dawley Rats
}

\author{
Nwaehujor Chinaka O., ${ }^{1,}$, Eban Linus K. ${ }^{2}$, Ode Julius O. ${ }^{3}$, Ejiofor Charles E. ${ }^{4}$, Igile Godwin $0 .{ }^{1}$ \\ ${ }^{1}$ Department of Biochemistry, Faculty of Basic Medical Sciences, University of Calabar, P.M.B. 1115 Calabar, Nigeria \\ ${ }^{2}$ Department of Pharmacology, Faculty of Medical Sciences, University of Calabar, P.M.B. 1115 Calabar, Nigeria \\ ${ }^{3}$ Department of Veterinary Pharmacology and Toxicology, Faculty of Veterinary Medicine, University of Abuja, Nigeria \\ ${ }^{4}$ Department of Veterinary Parasitology, Faculty of Veterinary Medicine, University of Abuja, Nigeria \\ *Corresponding author: chinaka_n@yahoo.com
}

Received September 16, 2014; Revised October 17, 2014; Accepted October 20, 2014

\begin{abstract}
The hepatotoxic effects of the seeds of Aframomum melegueta (Grains of paradise), a spice were studied in Sprague-Dawley rats. Individual rat groups received sub-chronic exposure of the methanol seed extract at 300 $\mathrm{mg} / \mathrm{kg}$ for 7, 14 and 21 days respectively. Liver toxicity was evaluated with assay of circulating serum aspartate aminotransferase (AST), alanine aminotransaminase (ALT), alkaline phosphatase (ALP), albumin, total bilirubin concentrations and histopathology of the liver of treated experimental rats. Serum levels of AST significantly $(\mathrm{p}<0.05)$ increased progressively in extract-treated rats compared to the control from day 7 till the termination of the study (day 21). However, serum ALT, ALP and total bilirubin levels of test rats were only significantly $(\mathrm{p}<0.05)$ elevated relative to the normal on days 14 and 21 of the investigation. The dose $(300 \mathrm{mg} / \mathrm{kg})$ of extract produced AST value of $55.8 \pm 3 \mu \mathrm{L}^{-1}$ while the control was $32.2 \pm 1.9 \mu \mathrm{L}^{-1}$; and ALT value became $16.8 \pm 1.1 \mu \mathrm{L}^{-1}$ when control was $8.6 \pm 1.1 \mu \mathrm{L}^{-1}$ on day 21 ; Total bilirubin was $1.4 \pm 0.1 \mathrm{mgdL}^{-1}$ relative to control value of $0.5 \pm 0.2 \mathrm{mgdL}^{-1}$. The serum albumin levels of extract-treated rats were however, comparable with that of the normal rats throughout the study period. Histopathology of the rat livers revealed mild focal necrosis of hepatocytes at day 7 , moderate multifocal areas of hepatic necrosis at day 14 and severe, diffused necrosis of hepatocytes at day 21 of treatment with the extract. The results demonstrated that the methanol seed extract of A. melegueta was potent in inducing liver toxicity at the tested dose $(300 \mathrm{mg} / \mathrm{kg})$. Maximal caution should therefore be imbibed in prolonged excessive use of the plant seeds as spice in delicacies.
\end{abstract}

Keywords: Aframomum melegueta seeds, Wistar rats, toxicity, liver enzymes, albumin, bilirubin

Cite This Article: Nwaehujor Chinaka O., Eban Linus K., Ode Julius O., Ejiofor Charles E., and Igile Godwin O., "Hepatotoxicity of Methanol Seed Extract of Aframomum melegueta [Roscoe] K. Schum. (Grains of paradise) in Sprague-Dawley Rats." American Journal of Biomedical Research, vol. 2, no. 4 (2014): 61-66. doi: 10.12691/ajbr-2-4-1.

\section{Introduction}

Medicinal plants contain diverse bioactive metabolites with useful therapeutic benefits and as precursors for a wide range of drug design. Herbal medication has been a popular practice for treatment of diseases and ailments since the ancient times. The roots, leaves, bark and seeds of plants were the principal sources of drugs used by the primitive man in the treatment of diseases (Meyer, 1962). The seeds of $A$. melegueta were well recognized by traditionalists in Mbaitoli Local Government Area, Imo State, Nigeria for healing effects in various health challenges including cough, stomach disorders, pile, abscesses, dysentery, rheumatism, fever, toothache and others. The seeds were reportedly valuable as remedy for stomach ache, snakebite, diarrhea, cardiovascular diseases, diabetes and inflammation (Ilic et al., 2010; Akendengue and Louis, 1994). The seeds were also listed in Arab folk medicine with carminative properties in due to the ability to relieve hyperacidity and to increase appetite (Amal Abdulaziz, 2010).

Aframomum melegueta belongs to the ginger family (Zingiberaceae) and is commonly called Grains of paradise, Malagueta (chilli pepper), Guinea pepper, Alligator pepper, Guinea grains, and Negro pepper (Beichner, 1961). It is variously known locally as ose oji, ataare and cittáá in Nigeria, Fam-wisa, wisa in Ghana and nengrekondre pepre in Liberia (Odugbemi, 2008; Daniel, 2004). The plant is a perennial deciduous herb native to the tropics and grows at the swampy habitats of the West African coast. It has leafy stem that may be up to $1.5 \mathrm{~m}$ high. The leaves are simple, alternate and lanceolate with matured ones measuring as long as $40 \mathrm{~cm}$ in length and 12-15 cm wide. It produces trumpet-shaped, purple colored flowers which develop into 5 to 7 long pods and each containing as many as 300 reddish-brown seeds 
(Dalziel, 1937). The seed of $A$. melegueta is used in different cultures. A small amount is given to an immediate new born baby to taste, serving as a welcome expression; the seeds are also offered as traditional wedding gift in Yoruba culture, Western Nigeria (Odugbemi, 2008). Alligator pepper is chewed with kolanut where the hot spicy taste reduces the bitter taste from kola nut in Ibo culture, Eastern Nigeria. It had been employed in divination and ordeal to determine the guilt among Efik people in Eastern Nigeria (Simons, 1956), religious (voodoo) rites in the Caribbean Islands (Voeks, 2013), to flavor alcoholic drinks (Harten, 1970) and as replacement for black pepper in European and American cuisines (Voeks, 2013).

The presence of the seeds of $A$. melegueta in the diet is considered to be responsible for the cardiovascular health of gorillas in the wild (Dybas and Ilya, 2007). The aqueous seed extract exhibited anti-inflammatory and peripheral analgesic activities (Umukoro and Ashorobi, 2001). It was used for medicinal purposes due to its antiinflammatory and antimicrobial activities, to relieve dental pains, asthma and body weakness, enhance body activities and preservation of grains (Ukeh et al., 2011). The sharp and peppery taste of the seeds is reportedly caused by the presence of aromatic ketones: 6-paradol, 6-gingerol and 6shogaol as part of its content (Sugita et al., 2013). Essential oils which are the dominating flavor components, is said to occur only in traces (Echo et al., 2012).

The present study sought to evaluate the hepatotoxic effects of the methanol seed extract of $A$. melegueta seeds on Sprague-Dawley rats under prolonged exposure.

\section{Materials and method}

\subsection{Collection of Plant Material and Extraction}

Dried Alligator pepper (A. melegueta) fruits were purchased locally from Ogige market in Nsukka Local Government Area, Enugu State, Nigeria. The seeds (1800 g) were removed from their seats within the fruit, air dried and the dried seeds later powdered using an electric blender (Moulinex, China). The material was de-fatted with petroleum ether using a Soxhlet extractor at $40^{\circ} \mathrm{C}$ to remove impurities. The dried marc was further macerated with intermittent shaking in $80 \%$ methanol at room temperature for $48 \mathrm{~h}$. It was filtered and the filtrate then dried in a rotary evaporator at $40^{\circ} \mathrm{C}$.

\subsection{Animals}

Adult Sprague-Dawley rats (128-175 g) of both sexes obtained from the Laboratory Animal unit of the Faculty of Veterinary Medicine, University of Nigeria, Nsukka (UNN) were used for the study. Animals were kept in stainless steel cages and had access to a predetermined mass of feed (Vital feed ${ }^{\circledR}$, Nigeria Ltd.) but water was provided ad libitum. Animal room temperature and relative humidity were $19-22^{\circ} \mathrm{C}$ and $30-70 \%$, respectively, and there was a $12 \mathrm{~h} \mathrm{light/dark}$ cycle. The rats were allowed 14 days to acclimatize prior to commencement of experiments. The use of the animals conformed with internationally accepted standards for laboratory animal use and care as documented in the European Community guidelines, Council Directive, 1986 (86/609/EEC), revised in Directive 2010/63/EU. The experimental protocols were approved by the Ethics Committee for Animal Experimentation, UNN, in accordance with Nigerian Federal Government legislation on Animal care.

\subsection{Acute Oral Toxicity Studies}

Acute toxicity studies were conducted using the method described by Lorke (1983). Thirty (30) matured mice of both sexes were marked, weighed and randomly separated into 6 groups $(\mathrm{A}-\mathrm{F})$ of 5 mice each. Groups A-E were given varying oral doses (150, 300, 600, 1500 and 2000 $\mathrm{mg} / \mathrm{kg}$ ) of the methanol seed extract of $A$. melegueta respectively, while group $F\left(6^{\text {th }}\right.$ group) received an equivalent volume $(10 \mathrm{ml} / \mathrm{kg})$ of distilled water. All treatments were given orally by gastric intubation. The mice were observed for signs suggestive of toxicity within $48 \mathrm{~h}$ and further monitored for two weeks for toxic effects.

\subsection{Experimental Design}

A total of 20 Sprague-Dawley rats were grouped into 4 . Group 1 served as normal control and received only the vehicle (distilled water, $10 \mathrm{ml} / \mathrm{kg}$ ) while Group 2, Group 3 and Group 4 received $300 \mathrm{mg} / \mathrm{kg}$ of the extract daily for 7 , 14 and 21 days respectively. The dose selection was based on results of the preliminary studies and the planned human exposure in the potential nutritional supplement. The individual rat dose was calculated based on the most recent weekly body weight of each animal. Extract concentration was then adjusted each week to maintain the targeted dose level for each animal (i.e., $300 \mathrm{mg} / \mathrm{kg} /$ day) for the extract to be administered at a constant volume of $5 \mathrm{ml} / \mathrm{kg}$. Each animal was drenched by oral gavage (using a stainless steel ball-tipped gavage needle attached to an appropriate syringe) daily at approximately the same time $\pm 5.0 \mathrm{~min}$ throughout the study period. The first day of administration was considered day 1 of the study.

\subsection{Clinical Observations}

All animals were observed twice daily for mortality. Cage-side observations were made daily during the study and any abnormal findings recorded. Detailed observations were recorded on day 1 (prior to administration of extract) and weekly thereafter on all animals. These observations were conducted both while handling the animal and with the animal placed in an open field. Observations included, but were not limited to: changes in skin, fur, eyes, and mucous membranes, occurrence of secretions and excretions and autonomic activity (e.g., lacrimation, piloerection, pupil size, unusual respiratory pattern). Changes in gait, posture and response to handling as well as the presence of colonic or tonic movements, stereotypes (e.g., excessive grooming, repetitive circling), or aberrant behavior (e.g., selfmutilation, walking backwards) were also recorded.

\subsection{Body Weights and Feed Consumption}

Individual body weights were recorded twice during the acclimation period, at study initiation (day 1), and weekly thereafter. Mean body weight gains were determined for each group at each interval and for the overall (days 7, 14 and 21) testing interval. The experimental rats were fed in 
accordance with the normal feed consumption of rats at 10 g feed/100 g body weight/day (Hafez, 1970). The amount of feed consumed in each group was compared with that of the control. Animals were also weighed immediately prior to sacrifice (fasted body weight) for calculation of organ to body weight.

\subsection{Biochemical Assay}

At the end of the test period for each group, blood samples were collected through the ocular retrobulbar plexus of the rats into separate test tubes. Samples were allowed to clot at room temperature before they were centrifuged at 2,500 rpm for $10 \mathrm{~min}$ to separate the serum. Serum from individual animal was used for biochemical assays. The serum levels of ALT and AST were determined using the method of Reitman and Frankel (1957), ALP level by the method of King and King (1954), total bilirubin concentration by the method of Malloy et al. (1937) as modified by Tietz (1996) and serum albumin level by the method Kinsley and Frankel (1939).

\subsection{Necropsy, Relative Organ Weights and Histopathology}

\subsubsection{Necropsy}

At scheduled periods for each group on days 7, 14 and 21 , rats were euthanized by exsanguination from the abdominal aorta under isoflurane anesthesia. Isoflurane (5-10 ml) was placed on gauze and administered to the rats enclosed in a bell jar. The animals were placed on the perforated surface above the gauze so they were never in contact with the liquid. The animals were monitored until anesthetized by checking for the absence of reflexes (pain response to pinch test) and that respiration was even and unlabored. Gross necropsy included an initial examination of external surfaces and orifices, as well as the cranial, thoracic and abdominal cavities and their contents. Rats were examined for gross lesions.

\subsubsection{The relative organ Weights}

The liver, kidneys, heart, spleen, and stomach of all sacrificed animals were weighed wet as soon as possible after dissection to avoid drying using a weighing balance (Metler, England). The relative organ weight of each rat was determined. Relative organ weight referred to the ratio of the weight of the organ to body weight.

\subsubsection{Histopathology}

Samples of the liver from the experimental animal groups were preserved in neutral buffered $10 \%$ formalin for minimum of $24 \mathrm{~h}$. The tissues were dehydrated by washing in ascending grades of ethanol before clearing with xylene and embedding in paraffin wax. The samples were sectioned with a microtome, stained with Hematoxyline and Eosin ( $\mathrm{H}$ and $\mathrm{E}$ ) and mounted on Canada Balsalm. All sections were examined under light microscope (x10, x20 and x40) magnification. Photographs of the lesions were taken with an Olympus photo microscope for observation and documentation of histopathological lesions.

\subsection{Statistical Analysis}

All data collected were subjected to one-way analysis of variance (ANOVA) and Duncan New Multiple Range Test (DNMRT) as post hoc to separate the treatment means. Differences at $\mathrm{p}<0.05$ were considered significant.

\section{Results}

\subsection{Description of the Extract}

The methanol extract of $A$. melegueta seeds was dark brown in color and with a peculiar fragrance. The extraction process gave a yield of $32.76 \% \mathrm{w} / \mathrm{w}$.

\subsection{Acute Toxicity Test}

Acute toxicity studies revealed no extract-induced mortality or overt serious clinical manifestation even at the highest test dose of $2000 \mathrm{mg} / \mathrm{kg}$. However, transient restlessness was observed in animals treated with the extract doses above $600 \mathrm{mg} / \mathrm{kg}$.

\subsection{Clinical Signs}

There were no extract related mortalities during the prolonged (21 days) study period, however one female died on test day 6 as a result of an intubation error. Transient clinical signs, most prevalent on day 14 included soft fecal droppings (2/5 males; $1 / 5$ females) and uro-genital staining (1/5 males). In addition, one female had ocular discharge on test day 21.

\subsection{Body Weights and Feed Consumption}

There was a significant $(\mathrm{p}<0.05)$ and time dependent decrease in the mean body weight of all rats that received the extract $(300 \mathrm{mg} / \mathrm{kg}$ ) relative to normal ones. The $12.5 \%$ lose in weight of the experimental rats on day 21 was most remarkable compared to 5.4 and $6.4 \%$ weight loses on days 7 and 14 respectively (Table 1 ). The mean daily feed consumption of the test rats was however, comparable with that of the control value within the overall duration of study (21 days).

Table 1. Effects of A. melegueta methanol seed extract $(300 \mathrm{mg} / \mathrm{kg})$ on rat body weight

\begin{tabular}{|c|c|c|c|}
\hline \multicolumn{4}{|c|}{ Mean weights (g) } \\
\hline Duration & Initial & Final & Mean difference ( \pm S.E.) \\
\hline Normal (control) & 180.2 & 188.6 & $8.4 \pm 1.6(4.7 \%)+$ \\
\hline 7 days & 218.6 & 206.9 & $11.7 \pm 1.2(5.4 \%)^{-*}$ \\
\hline 14 days & 198.9 & 186.2 & $12.7 \pm 0.8(6.4 \%))^{*}$ \\
\hline 21 days & 208.2 & 182.2 & $26.0 \pm 2.2(12.5 \%))^{*}$ \\
\hline
\end{tabular}

${ }^{+}$Weight gain compared to test groups; ${ }^{*}$ Significant weight lose compared to control value at $\mathrm{p}<0.05$.

\subsection{Biochemical Analyses}

The administration of the extract (300 $\mathrm{mg} / \mathrm{kg}$ ) caused elevation in AST, ALT, ALP and total bilirubin levels of test rats. The observed increases in the rat serum AST were progressive and significant $(\mathrm{p}<0.05)$ right from day 7 till the end of the study at day 21 but ALT, ALP and total bilirubin values became only significantly $(p<0.05)$ 
increased compared to the normal from day 14 to the termination of the investigation. There were no significant ( $p>0.05$ ) variations in the serum albumin concentration of rats that were treated with the extract relative to the control (Table 2).

Table 2. Serum enzymes, albumin and total bilirubin of rats under sub-chronic treatment with A. melegueta seed extract ( $300 \mathrm{mg} / \mathrm{kg})$

\begin{tabular}{|c|c|c|c|c|c|}
\hline Duration & AST $(\mu \mathrm{L}-1)$ & ALT $(\mu \mathrm{L}-1)$ & ALP $(\mu \mathrm{L}-1)$ & albumin $(\mathrm{mgdL}-1)$ & Total bilirubin $(\mathrm{mgdL}-1)$ \\
\hline Normal (control) & $32.2 \pm 1.9$ & $8.6 \pm 1.1$ & $25.2 \pm 1.7$ & $0.8 \pm 0.2$ & $0.5 \pm 0.2$ \\
\hline 7 days & $47.6 \pm 2.5^{*}$ & $12.4 \pm 1.0$ & $29.0 \pm 1.1$ & $0.7 \pm 0.1$ & $0.7 \pm 0.1$ \\
\hline 14 days & $54.4 \pm 1.7^{*}$ & $13.2 \pm 1.2^{*}$ & $34.3 \pm 1.2^{*}$ & $0.6 \pm 0.3$ & $1.1 \pm 0.2^{*}$ \\
\hline 21 days & $55.8 \pm 3.0^{*}$ & $16.8 \pm 1.1^{*}$ & $37.5 \pm 1.4^{*}$ & $0.5 \pm 0.2$ & $1.4 \pm 0.1^{*}$ \\
\hline
\end{tabular}

*Significant at $\mathrm{p}<0.05$; AST $=$ aspartate aminotransferase; ALT= alanine aminotransaminase; ALP $=$ alkaline phosphatase

\subsection{Necropsy}

No gross abnormalities of toxicological significance were noted for any of the euthanized animals during necropsies at the conclusion of the 21-day observation period. The organs of the experimental animals that received the extract could not easily be differentiated visibly for any lesion deviating from those of the control appearance.

\subsection{Effect of the Extract on Rat Body Weight and Mean Relative Organ Weights}

The methanol extract of $A$. meleguata $(300 \mathrm{mg} / \mathrm{kg}$ ) induced no observable changes in the absolute and relative weight of the organs (spleen, kidney, heart and stomach) of test rats that contrasted the normal with the exception of the liver. There were significant $(\mathrm{p}<0.05)$ progressive decreases in the mean relative liver weights of extracttreated rats compared to control on days 14 and 21 of the study. The mean relative liver weight of control rats was $25.3 \times 10^{-3} \mathrm{~g} \pm 0.9$ but that of test rats on days 14 and 21 were $20.01 \times 10^{-3} \mathrm{~g} \pm 0.4$ and $1.8 \pm 0.5 \times 10^{-3} \mathrm{~g}$ respectively (Table 3).

Table 3. Effects of Aframomum melegueta methanol seed extract on relative organ weights

\begin{tabular}{|c|c|c|c|c|c|}
\hline \multicolumn{6}{|c|}{ Weights x10 -3 g (mean \pm S.E.) } \\
\hline Duration & Liver & Spleen & Kidney & Heart & Stomach \\
\hline Normal (control) & $25.3 \pm 0.9$ & $5.9 \pm 0.1$ & $5.5 \pm 0.6$ & $4.1 \pm 0.2$ & $6.4 \pm 0.2$ \\
\hline 7 days & $24.7 \pm 0.6$ & $4.6 \pm 0.3$ & $5.5 \pm 0.2$ & $3.7 \pm 0.2$ & $7.2 \pm 0.1$ \\
\hline 14 days & $20.0 \pm 0.4^{*}$ & $6.2 \pm 0.2$ & $4.3 \pm 0.3$ & $3.9 \pm 0.5$ & $0.85 \pm 0.2$ \\
\hline 21 days & $1.8 \pm 0.5^{*}$ & $4.8 \pm 0.4$ & $4.8 \pm 0.7$ & $4.0 \pm 0.2$ & $0.53 \pm 0.1$ \\
\hline
\end{tabular}

\subsection{Histopathology of the Experimental Rat Livers}

Histopathological study of the livers of rats treated with the methanol seed extract of A. melegueta at $300 \mathrm{mg} / \mathrm{kg}$ for 7 days (group I), 14 days (group II) and 21 days (group III) was carried out.

Group I (Rats treated with the methanol seed extract (300 mg/kg) for 7 days): The liver of the rats had mild focal necrosis of hepatocytes (Plate I).

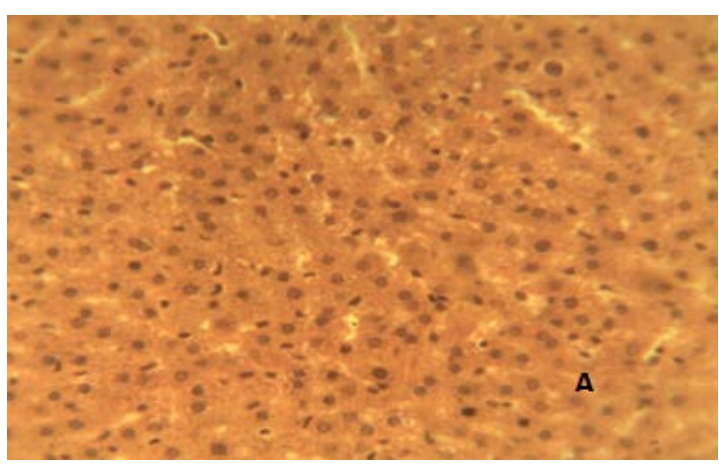

Plate I. Section of the liver of a rat treated with methanol seed extract (300 mg/kg) for 7 days. Note the mild focal necrosis of the hepatocytes (A). $\mathrm{H}$ and $\mathrm{E}$ stain. $\mathrm{x} 400$

Group II (Rats treated with the methanol seed extract (300 mg/kg) for 14 days): The liver had moderate multifocal areas of necrosis of the hepatocytes (Plate II).

Group III (Rats treated with the methanol seed extract (300 mg/kg) for 21 days): The rat liver was congested and had severe, diffused necrosis of the hepatocytes (Plate III).

Group IV (Normal rats): The micrograph of the liver showed no damage to liver cells. Hepatocytes were seen arranged in trabeculae separated by sinusoids containing Kupffer cells. Hepatocytes were regular and contained spheroidal nuclei with distinctly marked nucleoli (Plate IV).

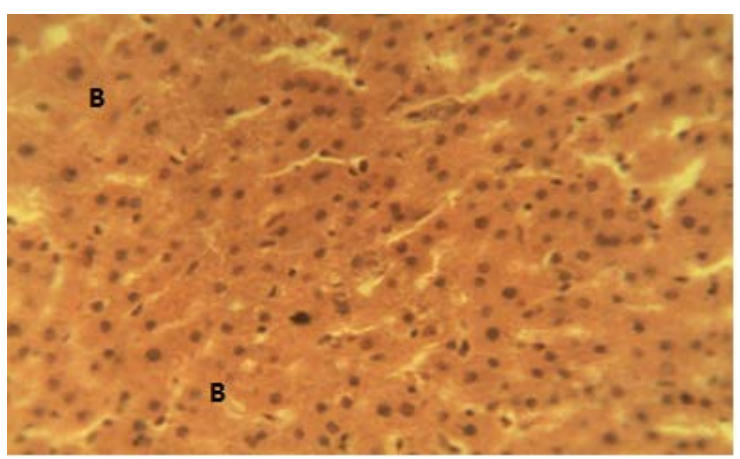

Plate II. Section of the liver of a rat treated with methanol seed extract (300 mg/kg) for 14 days. Note the moderate multifocal areas of necrosis of the hepatocytes (B). $\mathrm{H}$ and $\mathrm{E}$ stain. $\mathrm{x} 400$

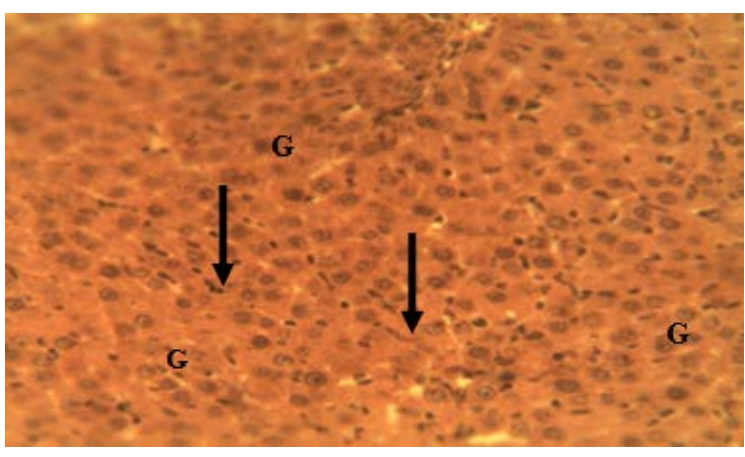

Plate III. Section of the liver of a rat treated with methanol seed extract (300 mg/kg) for 21 days. Note the congestion (arrow heads) and severe diffuse necrosis of the hepatocytes (G). H and E stain. x400 


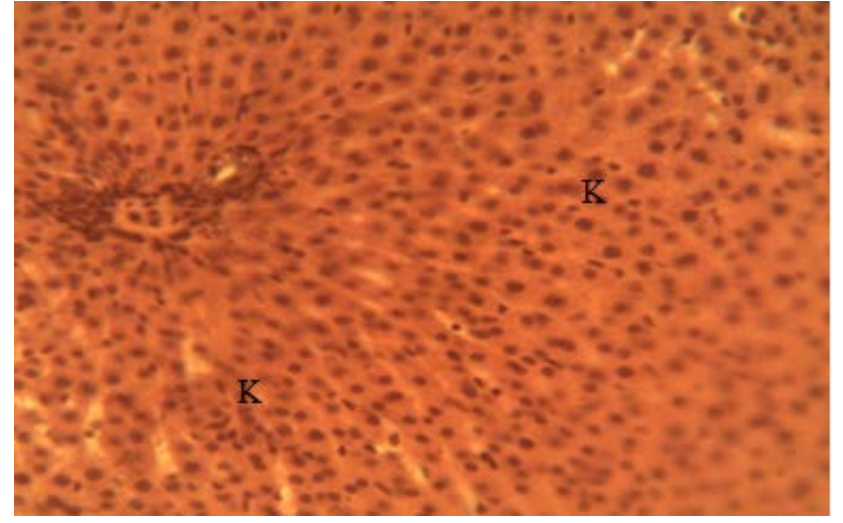

Plate IV. Normal rat liver. $\mathrm{K}=$ normal hepatocytes; H and E stain. $\mathrm{x} 400$

\section{Discussion}

The crude methanol seed extract of $A$. melegueta was tolerated by experimental rats since the highest test dose (2000 mg/kg) did not cause mortality or overt clinical pathology in the animals with $48 \mathrm{~h}$ duration of the study. The extract $(300 \mathrm{mg} / \mathrm{kg})$ induced a significant $(\mathrm{p}<0.05)$ decrease in the mean body weight of all the rats treated, and this manifested in the gradual weight loses of 5.4, 6.4 and $12.5 \%$ compared to the normal rats at 7,14 and 21 days respectively. It is logical for the animals to experience weight loses in situations of hepatotoxicity. Liver is a vital organ in the body and it carries on numerous important steps in the metabolism of all three kinds of foods: proteins, fats and carbohydrates, and also produces plasma proteins as well as vital enzymes (Thibodeau and Patton, 1999). Toxic injury to hepatocytes impairs the routine functions of the liver and induces defective utilization of energy sources which could invariably lead to weight lose in animals. Prolonged aflatoxin toxicity have been reported to lower egg production in poultry, suppressed immune responses, decreased body weight and milk yield in different animal species (Robens and Richard, 1992).

Treatment of rats with the extract $(300 \mathrm{mg} / \mathrm{kg}$ ) caused significant $(\mathrm{p}<0.05)$ increases in serum AST, ALT, ALP and total bilirubin levels but unchanged albumin values of test rats relative to the control, particularly on days 14-21 of the study (Table 2). Hepatic cells contain higher concentrations of AST and ALT in the cytoplasm and AST in particular exists in the mitochondria (Wells, 1988; Jan shin, 2003). Damage to hepatic cells induces leakage of plasma to cause an increased level of hepato-specific enzymes in serum (Tolman and Rej, 1999). The measurement of AST, ALT and ALP levels serve as a means for indirect assessment of liver function. The elevation in total bilirubin level of test rats buttressed the extent of damage done to the liver tissue; hepatocytes were no longer in position to effectively conjugate bilirubin for excretion. However, this study was limited to sub-chronic treatment with the extract, hepatotoxicity had not reached a critical stage, and some hepatocytes remained viable in carrying out biosynthesis of albumin. Hence there was no alteration in albumin levels of treated and control rats.

The different organs (heart, stomach, spleen and kidney) examined post-treatment with the extract showed comparable weights with the control except liver. The mean relative liver weight of test rats significantly $(\mathrm{p}<0.05)$ decreased from the value of $25.3 \times 10^{-3} \mathrm{~g} \pm 0.9$ seen in the control, to $20.01 \times 10^{-3} \mathrm{~g} \pm 0.4$ and $1.8 \pm 0.5 \times 10^{-3} \mathrm{~g}$ on days 14 and 21 were respectively (Table 3 ). The weight loss in liver tissue may be related to the toxic effect of the extract. Certain toxic substances, e.g. oxamyl used in pesticides are known to decrease various organ weights in rat (Cohen, 1986).

The histo-morphology of the liver from treated rats showed that, $300 \mathrm{mg} / \mathrm{kg}$ of $A$. melegueta extract induced a time dependent progressive, degenerative lesions on hepatic tissue. These involved mild focal necrosis of hepatocytes at day 7 of treatment, moderate multifocal necrosis of hepatocytes at day 14 and then severe diffused necrosis of hepatocytes at termination of the study at day 21 (Plates I, II and III). The mechanism in which the extract damaged the rat liver was not fully understood but some hepatotoxic drugs produce their effects through toxic metabolites and immunological reaction (Krishna et al., 2009). Some of the drugs that damage liver include amiodarone, methotrexate, chlorpromazine, acetaminophen, pirprophen, amineptin, tetracycline, valproate (Lewis and Schiff, 1988; Yeung et al., 1993; Krishna et al., 2009) and many more.

In conclusion, the findings suggest that the methanol extract of $A$. melegueta seeds is potentially hepatotoxic at $300 \mathrm{mg} / \mathrm{kg}$ under prolonged ingestion at high dose. This is supported by the remarkable decrease in the mean body weight of all extract-treated rats, elevation in serum AST, ALT, ALP and total bilirubin, decrease in the mean relative liver weight of test rats compared to the control and histopathological lesions on treated rat livers. Further studies are however, ongoing to isolate the hepatotoxic principle(s) in the extract and to determine the mechanism(s) of action.

\section{References}

[1] Akendengue B and Louis AM (1994). Medicinal plants used by the Masango people in Gabon. Journal of Ethnopharmacology 41 (3): 193-2000.

[2] Amal Abdulaziz B (2010) Prevalence of crude drugs used in Arab folk medicine available in Makkah Al-Mukarramah area. International Journal of Medicine and medical Science 2 (9): 256262.

[3] Cohen SZ (1986) Monitoring ground water for pesticides- Office of pesticide programme (TS-769C) - Environmental Protection Agency by American Chemical Society, Washington DC.

[4] Council Directive 1986 86/609/EEC on the approximation of laws, regulations and administrative provisions of the member states regarding the protection of animals used for experimental and other scientific purposes (86/609/EEC), European Commission, Brussels (1986).

[5] Beichner PE (1961) The grain of paradise. Speculum 32 (2): 302307.

[6] Dalziel JM (1937) The useful plants of West Tropical Africa. The Crown Agents for the Colonies, London. pp. 52-560.

[7] Daniel FA (2004) Florida Ethnobotany. CRC press, USA. p. 170.

[8] Directive 2010/63/EU of the European Parliament and of the Council of 22 September, 2010 on the protection of animals used for scientific purposes, European Commission, Brussels (2010).

[9] Dybas CL and Ilya R (2007) Out of Africa: A tale of gorillas, heart disease and a swamp plant. Bioscience 57: 392-397.

[10] Echo IA, Osuagwu AN, Agbor RB, Okpako EC and Ekanem BE (2012) Phytochemical composition of Aframomum melegueta and Piper guineense seeds. World Journal of Applied Environmental Chemistry 2 (1): 17-21. 
[11] Hafez ESE (1970) Reproductive and breeding techniques for laboratory animals. Lea Fabiger, Philadelphia. pp. 10-31.

[12] Harten AM (1970) Melegueta pepper. Economic Botany 24 (2): 208-216.

[13] Ilic N, Schmidt BM, Poulev A and Raskin I (2010) Toxicological evaluation of grains of paradise (Aframomum melegueta [Roscoe] K. Schum). J. Ethnopharmacol. 127 (2): 352-6.

[14] Jan Shin WU (2003) Transaminase GOT (AST) and GPT (ALT). International Journal of Pharmacology 1: 1-9.

[15] Kinsley SR and Frankel SJ (1939) The determination of serum total protein and albumin- globulin ratio. J. Biol. Chem. 128: 1317.

[16] King EJ and King PR (1954). Estimation of phosphatase by determination of hydrolyzed phenol with antipyrin. J. Clin. Pathol. 7: 322-331.

[17] Krishna KL, Mruthunjaya K and Patel JA (2009). Antioxidant and hepatoprotective activity of leaf extract of Justicia gendarussa Burm. Int. J. Biol. Chem. 3: 99-110.

[18] Lewis JH and Schiff E (1988). Methotrexate-induced chronic liver injury: guidelines for detection and prevention. Am. J. Gastroenterol. 83: 1337.

[19] Lorke D (1983). A new approach to practical acute toxicity testing, Archi. Toxicol. 54: 275-287.

[20] Malloy HT and Evelyn KA (1937) The determination of bilirubin with the photometric colorimeter. J. Biol. Chem. 119: 481-490.

[21] Meyer LJ (1962) Veterinary Pharmacology and Therapeutics ( $3^{\text {rd }}$ ed.). Iowa State University press, USA. p. 6

[22] Odugbemi T (2008) A textbook of Medicinal plants in Nigeria. Tolu press Lagos. p. 23-97.

[23] Reitman S, Frankel S (1957) A colorimetric method for determination of serum glutamate oxaloacetate and glutamic pyruvate transaminase. Am. J. Clin. Pathol. 28: 56-58.

[24] Robens JF and Richard JL (1992) Aflatoxins in animals and human health. Rev. Environ. Contam. Toxicl. 127: 69-94.
[25] Simons DC (1956) Efik divination, ordeals, and omens. Southwestern Journal of Anthropology 12 (2): 223-228.

[26] Sugita J, Yoneshiro T, Hatano T, Aita S, Ikemoto T, Uchiwa H, Iwanaga T, Kameya T, Kawai Y. and Saito, M. (2013). Grains of paradise (Aframomum melegueta) extract activates brown adipose tissue and increases whole-body energy expenditure in men. British Journal of Nutrition 110 (4): 733-738.

[27] Tietz N (1996) Liver function tests, nitrogen metabolites and renal function In: Fundamentals of Clinical Chemistry $3^{\text {rd }}$ ed. $W$. B. Saunders, Philadelphia. pp. 476-576.

[28] Thibodeau GA and Patton KT (1999) Anatomy \& Physiology (4 ed.). Mosby Missouri, USA. pp. 753-756.

[29] Tolman KG and Rej R (1999) Liver function. In: Tietz Textbook of Clinical Chemistry ( $3^{\text {rd }}$ ed.). Burtis, C.A. and Ashwood, E.R. (Eds.) W.B. Saunders, Philadelphia, PA., USA. pp. 1125-1177.

[30] Umukoro S and Ashorobi RB (2001) Effect of Aframomum melegueta seeds on thermal pain and on carrageenin-induced edema. Nigerian Quaterly Journal of Hospital Medicine 11: 220225.

[31] Ukeh DA, Umoetok SB, Bowman AS, Mordue AJ, Pickett JA and Birkett MA (2011) Alligator pepper, Aframomum melegueta and Ginger, Zingiber officinale, reduce stored maize infestation by the maize weevil, Sitophilus zeamais in traditional African granaries. Crop protection 32: 99-103.

[32] Voeks R (2013) Ethnobotany of Brazil’s African Diaspora: The role of Floristic homogenization. African Ethnobotany in the Americas 395-416.

[33] Wells FE (1988) Tests in Liver and Biliary Tract Disease. In: Varleys Practical Clinical Biochemistry. Gowenlock, H.A. (Ed.). CRC Press, Florida. pp. 561-593.

[34] Yeung PK, Hubbard JW, Korchinski ED and Midha KK (1993) Pharmacokinetics of chlorpromazine and key metabolites. European Journal of Clinical Pharmacology 45 (6): 563-9. 